\title{
Centenary of Pentecostalism in Ghana (1917-2017): A case study of Christ Apostolic Church International
}

\begin{tabular}{|c|c|}
\hline \multicolumn{2}{|c|}{$\begin{array}{l}\text { Author: } \\
\text { Peter White }{ }^{1}\end{array}$} \\
\hline \multicolumn{2}{|c|}{$\begin{array}{l}\text { Affiliation: } \\
{ }^{1} \text { Department of Science } \\
\text { of Religion and Missiology, } \\
\text { Faculty of Theology and } \\
\text { Religion, University of } \\
\text { Pretoria, South Africa }\end{array}$} \\
\hline \multicolumn{2}{|c|}{$\begin{array}{l}\text { Research Project Registration: } \\
\text { Project Leader: N. Niemandt } \\
\text { Project Number: } 04317734\end{array}$} \\
\hline \multicolumn{2}{|c|}{$\begin{array}{l}\text { Description: } \\
\text { Dr White is participating } \\
\text { in the research project, } \\
\text { 'Ecodomy', directed by } \\
\text { Prof. Dr Nelus Niemandt, } \\
\text { Department of Science of } \\
\text { Religion and Missiology, } \\
\text { Faculty of Theology and } \\
\text { Religion, University of } \\
\text { Pretoria. }\end{array}$} \\
\hline \multicolumn{2}{|c|}{$\begin{array}{l}\text { Corresponding author: } \\
\text { Peter White, } \\
\text { pastor_white@hotmail.com }\end{array}$} \\
\hline \multicolumn{2}{|c|}{$\begin{array}{l}\text { Dates: } \\
\text { Received: } 16 \text { July } 2018 \\
\text { Accepted: } 05 \text { Nov. } 2018 \\
\text { Published: } 31 \text { Jan. } 2019\end{array}$} \\
\hline \multicolumn{2}{|c|}{$\begin{array}{l}\text { How to cite this article: } \\
\text { White, P., 2019, 'Centenary } \\
\text { of Pentecostalism in Ghana } \\
\text { (1917-2017): A case study } \\
\text { of Christ Apostolic Church } \\
\text { International', HTS Teologiese } \\
\text { Studies/Theological Studies } \\
75(4) \text {, a5185. https://doi. } \\
\text { org/10.4102/hts.v75i4.5185 }\end{array}$} \\
\hline \multicolumn{2}{|c|}{$\begin{array}{l}\text { Copyright: } \\
\text { (C) 2019. The Authors. } \\
\text { Licensee: AOSIS. This } \\
\text { is licensed under the } \\
\text { Creative Commons } \\
\text { Attribution License. }\end{array}$} \\
\hline \multicolumn{2}{|l|}{ Read online: } \\
\hline 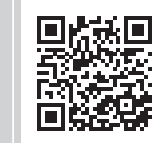 & $\begin{array}{l}\text { Scan this QR } \\
\text { code with your } \\
\text { smart phone or } \\
\text { mobile device } \\
\text { to read online. }\end{array}$ \\
\hline
\end{tabular}

Centenary celebrations in every organisation are approached with joy and reflection of the past, present, impact on society and planning for the years ahead. The Christ Apostolic Church International (CACI), which is acknowledged by Ghanaian Pentecostals as the mother of Pentecostalism, celebrated its Centenary of Pentecostalism in 2017. Having come this far and being acknowledged as the pioneer of classical Pentecostalism in Ghana, it is very important that issues concerning the church, its leadership and impact on society are discussed and properly recorded for future reference. Although some Ghanaian Pentecostal scholars did their best to document some aspects of history of CACI, their focus was limited to the early history of the church and the ministry of Apostle Peter Newman Anim. This article contributes to the existing missional and historical literature on CACI by bringing on board some of the historical gaps. This article also discusses the miraculous dispensation in CACI, their leadership and administrative structure, their growth and challenges as well as their religio-social and economic impact in Ghana.

\section{Introduction}

The Christ Apostolic Church International (CACI) takes pride in being the church that spearheaded the Pentecostal phenomenon in Ghana in the Classical Pentecostal Churches. The church is also accorded the recognition of being the first church in Ghana to have a similar experience of fire descending upon their church building at Asamankese on 23 May 1923 as it happened in Acts 1:1-3 (CACI 2016:2, 12; 2017a:8-9).

Although some Ghanaian Pentecostal scholars, such as Debrunner (1967), Larbi (2001), AsamoahGyadu (2005) and Omenyo (2006), did their best to document some aspects of history of CACI, their focus was limited to the early history of the church and the ministry of Apostle Peter Newman Anim. This article contributes to the existing missional and historical literature on CACI by bringing on board some of the historical gaps in the work of the above scholars. The article also discusses the miraculous dispensation in CACI, its leadership and administrative structure, its growth and challenges as well as its religio-social and economic impact in Ghana.

The study used literature study, historical method and observations as tools for data gathering, and the issues were discussed thematically.

\section{Brief background of Apostle Newman Peter Anim}

Apostle Newman Peter Anim (father of Ghanaian Pentecostalism), formally known as Kwaku Anim Mensah (also known as Kwaku Manasseh), was born on 04 February 1890 to Mr Simon Appiagyei and Madam Annah Lartebea of Boso in the Eastern Region of Ghana. He was the third of six children.

Newman had his lower primary education at the Basel Mission School at Boso in the Eastern region of Ghana from standards 1-3. He then continued his upper primary education at Anum Basel Mission from standard 4 to standard 7, finishing in 1908 (CACI 2017a:7). In 1911 he joined his brother at Amonokrom (Akuapem) and assisted him in his carpentry workshop. Later in the same year, he left for Pakro to work with the Basel Mission Factory as a weighing clerk. He left this job in 1912 because of ill health and later in 1914 became a bricklayer.

Newman finally left for Boso in 1916 and married Madam Dora Sakyibea the same year. Their marriage was blessed with four daughters, three of whom died in rapid succession during their infancy. Madam Dora Sakyibea died in 1920 after a short illness, and the remaining daughter died not long afterwards. Newman then married Madam Esther Osimpo and out of that wedlock was

Note: HTS 75th Anniversary Maake Masango Dedication. 
born Moses Appea-Anim, his only son and surviving child. Madam Esther Anim also died in 1967 (CACI 2017a:8).

Prior to Apostle Anim's Pentecostal orientation, he was a Presbyterian but later resigned from the church because of the influence he had from The Sword of the Spirit magazine, which was in circulation in Ghana. This magazine was edited by Pastor James Ambrose Clark, founder of the Faith Tabernacle ministry, Philadelphia (CACI Adult Sunday School Manual 2016:15). The insight gained from the reading of The Sword of the Spirit magazine informed Apostle Anim's decision for the formation of the Unity Prayer Group in 1917, which later became the CACI (CACI 2017a:8).

On the advice of his mentor Pastor Clark of the Faith Tabernacle Church, Anim submitted himself for water baptism by immersion on 03 December 1923. The baptism was administered by elder I.L. Bennet, one of his associates. Anim then added the name 'Newman' to his name to signify his new life found in Jesus Christ. Apostle Anim then continued his ministry until 1957 when he was forced into premature retirement as the head and spiritual leader of the church. He was later reinstated in 1960 as spiritual leader and Executive President of the CACI. Apostle Anim passed on to glory in 1984 (CACI 2017a:8-10).

\section{The Christ Apostolic Church International}

The Christ Apostolic Church as known today started in 1917 as the Unity Prayer Group and was later called the Faith Tabernacle Church because of the initial affiliation of Anim's prayer group to the Faith Tabernacle ministry, Philadelphia. Although The Faith Tabernacle was not a Pentecostal organisation, it had a strong emphasis on faith healing and holiness (CACI Adult Sunday School Manual 2016:12).

Apostle Peter Newman Anim and his group are credited with the origins of classical Pentecostalism in Ghana (Larbi 2001:32-33). Five years prior to the arrival of the first Pentecostal missionary from Europe in September 1932, Peter Anim and his Tabernacle Church were believed to have experienced baptism in the Holy Spirit. This experience is now being referred to as the 'Dispensation of the Holy Spirit in Ghana' (Atiemo 1993:21-22; Debrunner 1967:324).

The first generation of CACI members started the church as a prayer group. Prayer meetings were first held in Madam Dansoaa's house, and again in elder Asare Kwabena's house at Asamankese in the Eastern region of Ghana. Many people joined Anim's group through the healing and miracles they experienced. Testimonies about these healings spread throughout the regions, and several people believed their message. Anim, at this point, having been convinced of the truth of the teachings of Clark, adopted the name Faith Tabernacle for his Unity Prayer Group in 1922.

To reinforce the power base of the group, on 15 October 1922, a revival service was held in the house of one elder Kwabena
Asare and several converts were won. The healing and evangelistic activities of Anim attracted the attention of the then traditional chief of Asamankese, Nana Kwaku Amoah. Consequently, he offered them a parcel of land upon which they constructed their first new church building. The first church building of CACI was built in 1923 at Asamankese in the Eastern Region of Ghana. On 25 May 1923, the Holy Spirit revealed himself on top of the new church building in the form of fire during a 5-week revival at Asamankese. By 1923 Anim's movement had witnessed considerable growth (CACI Adult Sunday School Manual 2016:11).

In 1930, Apostle Anim stopped affiliating with the Faith Tabernacle because they did not believe in the speaking of tongues. He therefore sought for affiliation with the Apostolic Faith founded by Pastor Florence Louise Crawford to know more about baptism of the Holy Spirit and the gift of speaking in tongues (CACI Adult Sunday School Manual 2016:12). The name of Anim's church was then changed from the Faith Tabernacle Church to the Apostolic Church.

A major event that increased the publicity of Anim's organisation was the outbreak of the phenomenon referred to as Holy Spirit outpouring in 1932. Stephen Owiredu, a member of Anim's group, went into the bush at his Brekumanso village farm, which is near Asamankese, to pray for one of his twin babies who was sick. It was during the prayers that he had the extraordinary experience that Pentecostals refer to as the baptism of the Holy Spirit. When this news got to Anim at Asamankese, he and two brothers, Danso and Abokyi, and two sisters, Comfort Nyakoah and Oparebea, went to the village. A prayer meeting was held at the village during which the two sons of Owiredu and the two sisters, who accompanied Anim, also experienced baptism of the Holy Spirit (Shaw-Taylor 2014:4).

In 1936, Pastor Vivian Wellings, the then Missionary Secretary of the church in Bradford, visited the infant Apostolic Church at Asamankese. On his return to Bradford, England, he recommended that a resident missionary should be sent to Asamankese because the new church was growing at a fast rate. On 02 March 1937, Pastor James McKeown arrived in what was then known as the Gold Coast to take up the mantle as the first resident missionary and direct associate of Apostle Anim (Debrunner 1967:324; Omenyo 2006:94-95).

Pastor James McKeown was taken ill with malaria. A controversy broke out over his being taken to the Ridge Hospital by an English District Commissioner. This later led to a separation between Anim and McKeown in 1939 because of Anim's view on the doctrine of divine healing.

The fruit of their labour gave birth to the Christ Apostolic Church, the Apostolic Church Ghana and the Church of Pentecost (Asamoah-Gyadu 2005:23). Two of the three churches named here came into being as a result of a continuous reformation in Anim himself because of his constant acquisition of knowledge through his affiliations 
with foreign churches and their teaching about the Holy Spirit and his works in believers.

The early CACI members sold their properties and brought the money to support the church at Asamankese, an example was Apostle Daniel Owiredu, who sold his cocoa farm at Kwae. They established settlements, called faith homes or faith camps in many towns, where men and women with their families left their towns and villages to settle there permanently. Some bought plots of lands to build houses and farmed. Some of these faith homes were at Asamankese, Finte, Pepease, Poponya and so on. Life at these centres was extremely communal; they shared love meals and other material things together to meet their needs (CACI Adult Sunday School Manual 2016:13).

Some of the early leaders of the church are the following (CACI Adult Sunday School Manual 2016:14):

- Apostle Peter Newman Anim (leader).

- Pastor Nathan Danso (the first to become the general secretary).

- Elder Asare Kwabena.

- Brother Alex Amoah.

- Brother Timothy Obese.

- Brother Daniel Kofi Acheampong.

- Brother E.O. Okanta.

- Brother Timothy Adu (the man who wrote CACI hymns in 1926).

- Brother Abokyi.

- Madam Comfort Nyarko.

- Madame Beatrice Oparebe.

The organisation, in its early years, maintained two administrative centres: the general headquarters, based at Asamankese, and the missionary headquarters, based at Akim Oda. By 1952, the work had spread throughout the country. This therefore called for the creation of Pastoral Circuits in April 1952, namely, those of Asamankese, Akim Oda, Kumasi, Mandessim, Somanya, Winneba, Tarkwa, Nsawam, Accra, Boso and Keta. In November 1952, the executive again divided the country (the Gold Coast proper and the Ashanti) into areas, namely:

- Abuakwa Area, including Abuakwa, Agona, Akwapim and New Juaben.

- Kotoku Area, constituted of Kotoku, Fanti, Tardwa and Takoradi.

- Krobo Area, composed of Krobo, Togoland, Keta and Ga-Adangbe.

- Ashanti Area, composed of Ashanti, Sefwi and the Northern Territories.

Anim's organisation entered into a series of short-lived fellowships with different foreign bodies, the first being an American evangelical body known as the New Day Movement. Later on, there was another short-lived fellowship with the United Pentecostal Church (UPC), a Unitarian Pentecostal body in the United States.
As of December 2017, it has a total of 459 full-time ministers, 60 lay preachers, 116 administrative staff, 1 general deacon, 11 territorial deacons and 53 area deacons, making a total of 700 staff members for the church (CACI 2018a:4).

\section{The miraculous dispensation in Christ Apostolic Church International}

As part of the great commission, Jesus Christ said:

These signs will follow those who believe: In My name they will cast out demons; they will speak with new tongues; they will take up serpents; and if they drink anything deadly, it will by no means hurt them; they will lay hands on the sick, and they will recover. (Mk 16:17-18)

On another occasion, he said:

... most assuredly, I say to you, he who believes in me, the works that I do he will do also; and greater works than these he will do, because I go to my Father. (Jh 14:12-14)

This approach to ministry became part of the missional activities of the early church.

What makes the Acts of Apostles uniquely different from other books in the New Testament are the recorded miraculous acts performed through the apostles under the power of the Holy Spirit. In a similar way, Pentecostals believe in miracle signs and wonders that differentiate them from other Christian denominations. For Pentecostals, the presence of miracles means God is with them to transform lives and situations.

The dispensation of miracles in the CACI started with the founder Apostle P.N. Anim when he received healing for his 30-year-old stomach ulcer after reading about the healing testimonies written and published in The Sword of the Spirit magazine by Pastor James Ambrose Clark of the United States in 1917. After this experience of divine healing of Apostle Anim, there are records of several miracles that happened through and within the prayer group that later became known as the CACI. Some of the notable miracles are presented here.

One Mr Daniel Osei had divine healing from a deadly pestilence in 1921 at Asamankese through a prayer meeting of Apostle Anim (CACI Adult Sunday School Manual 2016:15). It has been recorded that one Apostle Daniel Owiredu raised back to life a half-dead prince at the Manhyia palace when he had been shot by someone. This miracle moved the then Ashanti king to donate a big plot of land freely to CACI at Bantama, Kumasi. This is how the Bantama Assembly got started in Kumasi. It was also noted that Apostle P.N. Anim visited some church members at a village near New Edubiase in the Central Region. The members complained to him about the shortage of fish and crabs in their river, their main source of food and income. Apostle Anim and the elders went to the riverside to pray. A week later there was a testimony of a heavy catch of fish and crabs for the river (CACI 2017b:13, 16). 
Apostle P.T. Gamah, under the instruction of the Holy Spirit, disguised himself as a madman dressed with a jute sack to preach on a market day at Tarkwa. He held a lantern in his hand during the preaching. Under the watchful eyes of the awe-stricken crowd, he continued to preach aggressively and drew many listeners to hear him. All of a sudden a mentally challenged man rushed into the crowd with a cutlass to kill Apostle Gamah. The mad man's hand turned stiff and remained in the air. People screamed and ran helter-skelter all over the place. He prayed for the mad man, his hand came down and the madness left him. He accepted Christ and was baptised. Eventually he became a pastor in the Christ Apostolic Church before the Lord called him to glory. That day many gave their lives to Christ at Tarkwa (CACI Adult Sunday School Manual 2016:16).

On another occasion while baptising his new converts, Apostle P.T. Gamah was bitten by a black cobra. He gave a loud prayerful cry 'Lord! I will not die'. He stopped the baptism, entered into a room and slept. In a vision an angel entered the room and drained the poison from his body. Apostle Gamah woke up from sleep totally healed (CACI Adult Sunday School Manual 2016:16).

According to the CACI's adults Sunday Bible class book (2016:17), at a village called Otaaprew near Agona Swedru, some traditional priests and medicine men accepted Christ and wanted their gods to be burnt, but when Prophet George Nyinaku poured a gallon of petrol on the heap of idols and other fetish materials and ignited fire to burn the petrolsoaked pile, it could not burn. Several matchsticks were lit but the pile would not burn. The Holy Spirit then directed the prophet to pour gallons of water on the fetish materials. He did this and the idols burst into flames and burnt into ashes.

On another occasion Prophet George Nyinaku commanded a coconut tree to shed its fruits when after several days of fasting, he and his prayer group were in need of coconut juice to break their fast. Amazingly the coconut tree under which he stood dropped five of its fruits at the command of Prophet George Nyinaku. Furthermore, it is on record that Prophet George Nyinaku prayed for the terribly sick son of prophetess Susanna Takyi, Obed Osam, at Asamankese. The young boy vomited pieces of broken bottles and was restored to normal health (CACI Adult Sunday School Manual 2016:17).

Several miraculous signs and wonders of healings and deliverances happened through the ministry of the apostles, prophets and pastors in CACI, when the Gospel was preached throughout the cities and villages of Ghana. These miraculous acts led to the spread of the church at various places.

In examining the growth of the church worldwide, one thing that is clearly evident is that not only is the church flourishing, it is often growing as a direct result of the effect of signs and wonders. According to Apostle Paul, through mighty signs and wonders, by the power of the Spirit of God, the gospel of Christ moved from Jerusalem and round about unto Illyricum
(Rm 15: 19). This informs Pentecostals not to only preach the gospel but also to believe God to work out miracles after the gospel is being preached.

\section{Leadership and administrative structure}

Church leadership plays an important role in the planting and the configuration of the missional congregation. The key to the formation of missional communities is their leadership (White 2015:1). Pentecostals' understanding of leadership starts with the kind of spiritual gift possessed by individuals, and how it has been developed. An important element of the Pentecostal theology is the emphasis on the 'gifts of the Spirit', which is often expressed in their literature as 'Charismatic gifts' (Asamoah-Gyadu 2005:7).

Leadership in the context of the CACI follows the apostolic pattern of leadership, also known as Fivefold Ministry (apostle, prophet, evangelist, pastor and teacher). Although the term 'Fivefold Ministry' cannot be found in the Bible, it has been accepted in many Pentecostal theological discourses on church leadership (Eph 4:11-12; DeSilva 2004:731). Some writers view the gifts of apostle, prophet, evangelist, pastor and teacher as offices (Wagner 1994:39), while others view them as functions (Fee 1994:707; Hirsch 2006:153; Witherington 2007:290-291).

According to article 9 of the draft constitution of the CACI, the Fivefold Ministry is the five leadership or governmental offices given to the church by Jesus Christ for the edification of the church and for the purpose of church administration and decisions on doctrinal and spiritual issues of the church (2018:20).

Furthermore, the constitution of the CACI defines the hierarchy of leadership in the church beginning with the General Council (2018:20).

\section{The General Council}

According to the constitution of the church, the General Council shall be the highest law and policy-making body of the church vested with the final authority to deliberate and make broad policies for the administration of the church in accordance with the constitution (2018b:20). The General Council is specifically composed of the following:

1. All Executive Council members.

2. All full-time ministers.

3. Territorial management members.

4. Area management members.

5. Three representatives from each area of the church, who shall be nominated by the area administration.

6. Two representatives from each ministry at the national level.

7. Representatives from foreign mission as may be determined by the Executive Council.

8. Observers who may be invited by the Executive Council but without voting rights. 
The constitution outlines the functions of the General Council to include the following (2018b:21):

- The General Council shall be the highest policy- and lawmaking body of the church and shall have power to ratify all matters and/or decisions that need approval by the General Council.

- The General Council shall examine, treat, approve and endorse annual, field and ministerial reports including memoranda sent to it by the National Executive Council and any other relevant body of the church.

- The General Council shall have the final powers of amending, promulgating and ratifying an amendment to the constitution by a 2/3 majority of the eligible members of the Council at a meeting for that purpose.

- The General Council shall have the final authority to vet and approve annual financial statements, budget proposals from the Executive Council and also examine and approve audit reports, which the Council shall have power to compel the Executive Council to submit to it.

- The General Council shall have the power to appoint external auditors to audit the accounts of the church every year and to submit its report to the General Council in accordance with the provisions of this constitution.

- The General Council shall elect all the elected members of the Executive Council.

The above roles imply that the structures of the church cannot function without the direction of the General Council. However, the day-to-day running of the church and implementation of administrative policies are under the direct supervision of the Executive Council.

\section{The Executive Council}

According to the constitution:

\begin{abstract}
... there shall be an Executive Council which shall be vested with the executive powers of the Church to administer the Church to achieve the mission, vision and objectives of the Church. In the exercise of its executive powers, the Executive Council shall have managerial and disciplinary powers and authority to implement the policies of the Church in accordance with this constitution. (CACI 2018b:22)
\end{abstract}

For the smooth running of the business of the church, the Executive Council consists of the following members:

1. The Chairman of the Church.

2. The Field Director.

3. The General Secretary.

4. The Director of Missions.

5. The Director of Evangelism.

6. The Director of Christian Education.

7. The Prophetic Director.

8. The Director of Finance.

9. A national elder who shall be appointed by the Chairman in consultation with the other members of the Executive Council.

10. Two other members who are not ministers but are eminent members of the church with special expertise and they shall be appointed by the Chairman in consultation with the other elected members of the Executive Council.

\section{Theological and leadership formation}

According to Van Rheenen (1996:164) congregational nurturing must always be preceded or coupled with leadership training. In the midst of this congregational nurturing, God raises leaders and places them in the body, just as he wants them to be. The key to the formation of missional communities is their leadership. Church leadership formation is therefore fundamentally important for the missiological purpose in the world (Guder 1998:183, 185).

Although the founder of the CACI was an avid reader and his reading habit affected his theological orientation and practices, he ended his ministerial life with no formal theological qualification.

Pentecostal's approach to leadership formation is twofold informal leadership formation and formal leadership formation (White 2015:6). From its inception, the CACI did not really consider the educational background of the people involved in their ministerial activities and those called into ministry. In their context, local churches are responsible for the informal leadership training of people. Leadership formation in this context depends on how committed one is to the development of his or her ministry gift. The focus here is on developing people's ministry gifts and placing them in positions within the church where they can function optimally. In many cases, people are placed under the mentorship of other senior church workers or leaders (White 2015:6-7).

Apart from the fact that the early leaders had little or no formal theological training, the church later established a Bible School at Kwadaso-Kumasi for the training of pastors. The pastoral training was organised intermittently. In October 2007, the General Council of the CACI passed a resolution to begin the process for tertiary degree programmes using the existing facility at Kwadaso in Kumasi. The processes for affiliation to the University of Cape Coast were approved in July 2010. On 19 February 2010, the National Accreditation Board granted the Christ Apostolic University College an approval of a 3-year authorisation with effect from 15 February 2011. Christ Apostolic University College (CAUC) started academic work in September 2011. The first batch of students reported for lectures in October 2011 (Christ Apostolic University College 2018).

\section{Analysis of the growth and leadership challenges}

Since its inception the CACI has suffered several challenges in the area of doctrine, leadership and breakaway churches. The church started affiliation with Faith Tabernacle Church, Philadelphia, US, because of the theological influences of Pastor Clark's movement on Anim's group.

Controversy developed among the Faith Tabernacle believers when Clark was excommunicated in 1926 for alleged adultery. Meanwhile, Anim had been receiving copies of 
another religious magazine published by a Pentecostal movement based in Portland, Oregon, USA, known as 'The Apostolic Faith'.

Anim therefore separated from the Faith Tabernacle in 1930 and adopted the name the Apostolic Faith in the same year. Anim suffered great opposition at the hands of pagan and religious persecutors in 1928, but this did not impair the progress of his movement. His attempts to share with the pastor-in-charge of the Faith Tabernacle in Accra the teachings on the Holy Spirit of the Apostolic Faith were unsuccessful, for the pastor thought Anim was in error. This, however, did not derail Anim from his course. He continued to give careful study to the Apostolic Faith teaching. Anim officially secured his affiliation with the UK Apostolic Church in 1935. This affiliation later led to the sending of Pastor James McKeown in 1937.

A further challenge Anim and his ministry had was the separation with McKeown based on the fact that McKeown went for medical treatment at Ridge Hospital, Accra, when he fell ill. This created a theological problem for Anim's followers, which later led to a separation between Anim and McKeown in 1939.

Anim conveyed the information about the separation of his movement from McKeown's organisation to the assemblies and a meeting was called at Pepeade, where Anim's organisation finally ended its affiliation with the Apostolic Church in June 1939.

Furthermore, the church also had leadership challenges when Anim was forced into a premature retirement in August 1957, after 40 years of service. His position was taken by Rev. D.K. Brifo. The new leadership was not able to fulfil the commitment made to Anim for his upkeep. Things did not go well for the new leadership under Rev. Brifo. Dissension and alleged financial impropriety were reported. Anim was unhappy about this development and he called for all the church workers to meet at Nsawam. At the meeting it was directed through prophecy that the headquarters of the church be moved from Asamankese to Accra forthwith. Anim's position as the leader of the organisation was also confirmed through prophecy. The meeting then charged the executive under Rev. Brifo with inefficiency and it was therefore dissolved immediately.

Apart from the above internal doctrinal and theological challenges that led to several affiliations and separation of Apostle Anim and Pastor James McKeown, the church also experienced several breakaway churches. Some of the notable churches are presented in Table 1.

These separations and breakaways affected the growth of the church. Leaders who broke away from CACI went away with some of the members to establish their own churches. Analysis of the reason for these separations was basically leadership challenges and inability of the church leaders to handle differences and conflicts.
TABLE 1: Breakaway churches from Christ Apostolic Church International.

\begin{tabular}{|c|c|c|}
\hline Name of church & $\begin{array}{c}\text { Year of } \\
\text { separation }\end{array}$ & Founder/leader \\
\hline $\begin{array}{l}\text { Christian Praise International } \\
\text { Church }\end{array}$ & 2003 & $\begin{array}{l}\text { Bishop Dr Annor-Yeboah } \\
\text { (former Acting Chairman of CACl) }\end{array}$ \\
\hline Christian Anointed Church & 1991 & Rev. D.C. Addo \\
\hline Asanteman CAC & 1989 & Rev. De-Graft Amanful \\
\hline Harvesters Church & 1983 & Rev. Gregory O. Ola \\
\hline Christ Apostolic Reformed Church & 1979 & Rev. D.K. Saforo \\
\hline United Pentecostal Church & 1969 & Rev. M.R. Asamoah \\
\hline Christ Revival Church & 1959 & Rev. D.K. Brefo \\
\hline New Day Church & 1949 & Rev. Yeboah \\
\hline
\end{tabular}

Furthermore, the church also has a very huge gap as far as leadership development is concerned. About $60 \%$ of the churches are without permanent, furnished churches (Amaning 2013:108). In addition, the church does not have strong policies and strategies for their international missionary churches and policies to assist such ministers to acquire the required visa for their missionary activities. Moreover, unlike the Church of Pentecost, which was founded by Pastor James McKeown (a missionary associate of Apostle Anim), many of the branches of the church have no mission houses.

Amaning (2013) submitted that:

Although Anim was a servant leader; his extreme view on divine healing (no medication) did not help the church in attracting professionals and intellectuals into the church. This therefore affected the growth, financial and infrastructural development of the church. (p. 100)

\section{Religio-social and economic impact of Ghanaian Pentecostalism}

Religion and culture impact are major economic determinants such as people's attitude to work for productivity, consumption, savings and investments, entrepreneurship and governance including accountability and transparency (Adei 2016). The church as an institution is itself a major economic and development agent of society. It also serves as the prophetic voice to both the vulnerable and political leaders in society.

The church as a religious and social organisation driven by moral and social principles as contained in the fundamental teachings and doctrine of the Christian faith is expected to play an important role towards the social transformation and improvement on society's value systems and practices. This is expected to lead to transformation of the social life and put society on holistic growth and position it in the direction of development (Akanbi 2017:11). The church is called to service (diakonia), in every geopolitical and socioeconomic context, living out the faith and hope of the community of God's people, and witnessing what God has done in Jesus Christ (Walls \& Ross 2008:35, 46-47). Diakonia is the church's practical and theological answer to God's call to save creation and humankind. Thus, it is the church's way of responding to the challenges of society (Lutheran World Federation 2002:11-12). According to Bosch 
(1991:100), the first words the Lukan Jesus speaks in public (Lk 4.18-19) contain a programmatic statement concerning his mission to reverse the destiny of the poor.

For Ghanaian Pentecostals, the Bible holds the key to the socioeconomic emancipation and remodification of Ghanaians. Socio-economic emancipation implies Christian stewardship of the resources that God has bestowed for our well-being. Mission statement of the CACI (Adult Sunday School Manual 2016) says that:

... the Christ Apostolic Church is a Christian organisation which seeks to bring salvation in Christ to all persons in the world who are perishing by preaching and teaching of the gospel of Christ as in the Holy Scriptures and promoting socioeconomic development. (p. vii)

Although Christians in the Gold Coast prayed for Ghana's independence, one significant event was in the 1950s when Dr Kwame Nkrumah, Dr Ebenezer Ako-Adjei and Mr Kojo Bostio consulted Apostle Anim and Prophet Joshua Alabi at a CACI prayer camp at Oyibi near Dodowa regarding Ghana's independence. Prophet Alabi prophesied to Nkrumah in 1956 that God would stop the British rule and transfer power to the people of Gold Coast. Nkrumah was assured by the Holy Spirit through Prophet Alabi that God had chosen him to lead Gold Coast. Truly, the Gold Coast became independent in 1957 and the Nation was renamed Ghana (CACI 2017b:16).

The Assemblies of God, CACI, the Apostolic Church and the Church of Pentecost were the founders of Ghana Pentecostal Council (GPC) from 1968 to 1969. Apostle Anim and his church were principal contributors to the formation of the council. He delegated Apostle Daniel K. Saforo (a living legend) to serve as a member of the first Executive Council of GPC in 1969.

In his keynote address at the 60th General Council Meeting of the CACI held from 26 to 28 April 2017, the Chairman, Apostle Stephen Kwame Ntow Amoani, disclosed that the church has successfully carried out the following as its contribution to national development:

- Establishment of Christ Apostolic Junior High School.

- Establishment of Christ Apostolic Commercial and Senior High School.

- The establishment of Christ Apostolic University College located at Kwadaso-Kumasi.

- Christ Apostolic Scholarship Scheme.

- Christ Apostolic Printing Press.

- Christ Apostolic Television.

- Establishment of Christ Apostolic Agency for Relief and Development (CAAR).

- Support to Ghana Heart Foundation.

At the climax of its centenary celebration on 12 November 2017, the church donated four ambulances to the Government of the Republic of Ghana to support emergency health care delivery in the country (CACI 2018a:3).

\section{Conclusion}

This article focused on the 100 year anniversary of the CACI. It discussed the history of the founder, Apostle Peter Newman Ainm, history of the church, the dispensation of miraculous activities that brought the church and its leadership to limelight. The church was noted to be the first in Ghana to be acknowledged as the pioneer of Ghanaian Classical Pentecostalism and its founder also known as the father of Pentecostalism in Ghana.

The article further discussed the leadership and leadership formation of the church as well as analysis of the growth and leadership challenges. It was noted that many of the leadership challenges were as a result of doctrinal, leadership challenges and inability of the church leaders to handle differences and conflicts. The article concluded with the religio-social and economic impact of Ghanaian Pentecostalism. It was unveiled that in spite of the challenges the church had, it has contributed significantly to the socioeconomic and political development of Ghana.

\section{Acknowledgements Competing interests}

The author declares that he has no financial or personal relationship(s) that may have inappropriately influenced him in writing this article.

\section{References}

Adei, S., 2016, 'The impact of Christianity on national development with special reference to the role of Pentecostalism', paper presented at the Christ Apostolic Church International Second Public Anim Memorial Lectures, 6th May.

Akanbi, S.O., 2017, 'Socio-economic and political impact of South-West Nigerian Pentecostal churches viewed from a Theological perspective', PhD submitted to the Department of Science of Religion and Missiology, Faculty of Religion and Theology, University of Pretoria, South Africa.

Amaning, W.K., 2013, 'A study of the leadership style of Jesus (Matt 20:26-28) and that of the leaders of Christ Apostolic Church International', MPhil thesis submitted to the School of Graduate Studies, Kwame Nkrumah University of Science and Technology, Kumasi.

Asamoah-Gyadu, K.J., 2005, African Charismatics: Current developments within independent Indigenous Pentecostalism in Ghana, EJ Brill, Leiden.

Atiemo, A.A., 1993, The rise of Charismatic movement in the mainline churches in Ghana, Asempa Publishers, Accra.

Bosch, D.J., 1991, Transforming mission: Paradigm shifts in theology of mission, Orbis Books, Maryknoll, NY.

Christ Apostolic Church International (CACI), 2016, Adult Sunday School Manual, CAC Press, Accra.

Christ Apostolic Church International, 2017a, Launching of Centenary brochure, CACI Press, Accra.

Christ Apostolic Church International, 2017b, Easter Convention brochure 2017, CACl Press, Accra.

Christ Apostolic Church International, 2018a, 2017 annual report presented at the 61st General Council meeting in May, 2018, CACl Press, Accra.

Christ Apostolic Church International, 2018b, Draft Constitution, CACI Press, Accra.

Christ Apostolic University College, 2018, from a brief History, viewed 20 June 2018, http://www.cauc.edu.gh/about.html

Debrunner, H.W., 1967, A history of Christianity in Ghana, Waterville Publishing House, Accra.

DeSilva, D.A., 2004, An introduction to the New Testament: Contexts, methods \& ministry formation, InterVarsity Press, Downers Grove, IL.

Fee, G.D., 1994, God's empowering presence: The Holy Spirit in the letters of Paul, Hendrickson Publishing Inc., Peabody, MA.

Ghana Pentecostal and Charismatic Council, 2018, History and background, viewed 18 June 2018, http://gpccghana.org/history-and-background/

Guder, D.L., 1998, Missional church, William B. Eerdmans Publishing Company, Grand Rapids, MI. 
Hirsch, A., 2006, The forgotten ways: Reactivating the missional church, Brazos Press, Grand Rapids, MI.

Larbi, E.K., 2001, Pentecostalism: The Eddies of Ghanaian Christianity, Blessed Publications, Accra.

Lutheran World Federation, 2002, 'Prophetic Diakonia: For the healing of the world', report from The Lutheran World Federation. Congress held at Johannesburg, South Africa, November 2002, pp.11-12, viewed 27 May 2018, from http://elcic ca/Documents/documents/PropheticDiakoniaConsultation_Diakonia2002.pdf

Omenyo, C.N., 2006, Pentecost outside Pentecostalism, Boekencentrum Publishing House, Netherlands.

Shaw-Taylor, E., 2013, 'The role of women in the church and in Christ Apostolic Church in particular', Scriptura 112(1), 4.
Van Rheenen, G., 1996, Biblical foundations and contemporary strategies: Missions, Zondervan Publishing House, Grand Rapids, MI.

Wagner, C.P., 1994, Your spiritual gifts can help your church grow, Monarch Publications Ltd., Great Britain.

Walls, A. \& Ross, C. (eds.), 2008, Mission in the 21st century: Exploring the five marks of global mission, Darton, Longman and Todd Ltd., London.

White, P., 2015, 'A missional study of Ghanaian Pentecostal churches' leadership and leadership formation', HTS Teologiese Studies/Theological Studies 71(3), Art. \#2865, 8 pages. https://doi.org/10.4102/hts.v71i3.2865

Witherington, B., 2007, The Letter to Philemon, the Colossians, and the Ephesians, William B. Eerdmans Publishing Company, Grand Rapids, MI. 